\author{
Journal of International Business Research and \\ Marketing \\ Volume 5, Issue 5, 2020 \\ journal homepage: www.researchleap.com
}

\title{
The Impact of Electronic Commerce on Motivating the Investment in the Kingdom of Saudi Arabia
}

\author{
${ }^{1}$ Thair A. Habboush, ${ }^{2}$ Badi F. Alanazi \\ ${ }^{1,2}$ University of Jeddah, Jeddah, Saudi Arabia
}

\begin{tabular}{|c|c|}
\hline & ABSTRACT \\
\hline $\begin{array}{l}\text { 2016 Research Leap/Inovatus Services Ltd. } \\
\text { All rights reserved. } \\
\text { DOI: } 10.18775 / \text { jibrm.1849-8558.2015.55.3002 } \\
\text { URL: } \underline{\text { http://dx.doi.org/10.18775/jibrm.1849- }} \\
\underline{8558.2015 .55 .3002}\end{array}$ & \multirow{2}{*}{$\begin{array}{l}\text { The study aimed to identify the impact of E-Commerce (regulations and legislations, } \\
\text { infrastructure, manpower) on stimulating investment in the Kingdom of Saudi Arabia. We } \\
\text { applied the descriptive-analytical method for achieving the study objectives. The questionnaire } \\
\text { was administered to collect the data that were then analyzed using the SPSS system to provide } \\
\text { answers for related questions and hypotheses. A random sample of } 250 \text { volunteering investors } \\
\text { was taken, and the number of respondents reached } 202 \text { respondents, which represents } 81 \% \text { of } \\
\text { the study population. We found that there is a significant impact of E-Commerce on motivating } \\
\text { the investment and the existence of a statistically significant correlation between the } \\
\text { independent variables as a whole were confirmed. The study also finds a substantial impact of } \\
\text { the age variable on the investment in the KSA at the level ( } \alpha=0.05 \text { ), and the differences emerge } \\
\text { of the age group ( } 31-40) \text {. A few recommendations are provided, such as intensifying the studies } \\
\text { within the subject domain by using different research methods. Further, another } \\
\text { recommendation is to conduct different practical scientific studies on the state level to develop } \\
\text { a structured and gradual mechanism for converting } 85 \% \text { of the conventional retail sector to E- } \\
\text { Commerce in accordance with the KSA vision in } 2030 \text {. }\end{array}$} \\
\hline $\begin{array}{l}\text { Keywords: } \\
\text { E-Commerce, Investment, Motivation, KSA }\end{array}$ & \\
\hline
\end{tabular}

\section{Introduction}

The dramatic development of communications and the intensified use of Internet led to the emergence of multiple applications in the business field, which result in the appearance of strong competition between enterprises to increase market shares (Nour Al-Dean, 2007). In this decade, the world is witnessing considerable leaps in the communications and information system as its costs continue to decline, leading to a radical change in the way individuals and institutions perform their business, and in the way, that money and information have been transferred. This was accompanied by an expansion in commerce and its practice, and also an increase in the markets and the multiplicity of its products (Ismail, 2010). The traditional form of commerce is no longer the only practice. As a result of Internet development and the role it plays as a mediator between the service provider and its recipients, the business practice circle has expanded to include the individuals in the competition department. This leads the large companies to rethink their traditional methods related to providing services to the primary consumer to retain their loyalty (Al-Tai, 2010).
The developed countries realized the importance of this sector and its rapid development. They rushed to legislate the laws and regulation related to commerce operations and also the enactment of laws that would protect its products, markets, and citizens, while the developing countries were late to realize the importance and size of E-Commerce. This caused their markets and products to be affected by the global competition without them having the ability to control the size and direction of this influence. Therefore, these countries were forced to catch up and initiate the regulation of this sector and legislate laws that align with its streams and specificity (Hammad, 2003). At the beginning of this century, many essential investment opportunities emerged in the E-Commerce sector at all levels (countries, companies, organizations, individuals), which were also accompanied by many challenges requiring a high level of knowledge, technology and organizing (Al-Jabbar \& Ahmed, 2018).

Because Kingdom of Saudi Arabia (KSA) is considered one of the strongest economies in the Middle East and also one of the largest markets in the region, the opportunity to advance ECommerce and the investment has emerged there before other 
markets in the region. This led the Kingdom to conduct studies on E-commerce and take the steps towards making a large-scale investment at all levels. In addition, KSA is considered to be the first Arab country by the number of Internet users for shopping purposes on the Arab world level (Saudi Ministry of Commerce and Investment, 2017). Accordingly, vision/ 2030 was designed to keep pace with this development in E-Commerce. One of its most important objectives was to transform retail commerce to E-Commerce instead of the current traditional popular method in the Kingdom (Al-Jadran, 2019).

\section{Study Problem}

For a long time, the Saudi economy has been able to attract foreign investment at rates higher than in other countries in the region. Kindom's long-term dependency on oil as a major source for the Saudi Gross National Product has destabilized its economic strength during the last decade. In the report issued by the United Nations Conference for Trade and Development in 2017, the foreign investment flows fell to their lowest levels despite the kingdom's large economic reform packages, and in the same report the Kingdom showed progress in E-Commerce. According to the report, Saudi Arabia ranks 46th out of 144 countries by its readiness to implement E-Commerce.

The research problem emerged in an attempt to investigate the impact of E-Commerce on motivating the domestic and foreign investments in the Kingdom and create multiple opportunities to turn the Saudi market into an attractive market for the investment. This study aims to identify the impact of ECommerce on motivating the investments in KSA.

\section{Study Importance}

KSA faced many economic challenges at the beginning of this century. Due to the fact that Kingdom's economy depends on the oil as a primary source of income and the kingdom's budget, the economy went through a recession and a decline as a result of the fluctuations of world oil market. This was accompanied by a decline in foreign investments which in turn reflected on the number of job opportunities and the reduced unemployment figures, especially the unemployment among university graduates. These challenges led the Kingdom to utilize the opportunities provided by multiple and open sections related to E-Commerce, especially on the regional or Arab level. This was a unique chance to address the weaknesses of the economy, and at the same time address a large part of the unemployment problem. Therefore, the Kingdom has embarked on legislating the regulations, laws, and rules that govern this commerce. The body was established to develop activities in line with the Kingdom's guidelines in Vision 2030 to transition from traditional commerce to the Electronic Commerce.

The scientific importance of this study is in the fact that it addresses one of the contemporary and emerging topics which affect the economy of KSA. The new subject of the impact of ECommerce on motivating the investments in KSA calls for more research, and this study contributes to the efforts of scientific researches in this field. Further investigation concerning the important facts and on the Kingdom level is provided. This study is one of the few analytical studies on the subject matter which were conducted at the Kingdom level. The author seeks to draw the most important conclusions and make some recommendations to benefit the decision-makers in the economic field.

\section{Study Objectives}

The study aimed to identify the impact of E-Commerce on motivating the investment in KSA through the achievement of the following sub-objectives:

- To illustrate the impact of the sex variable among sample members on investment at the Kingdom of Saudi Arabia.

- To show the impact of the age variable among sample members on investment at the Kingdom of Saudi Arabia.

- To identify the impact of a scientific level variable in the among sample members on investment at the Kingdom of Saudi Arabia.

- To show the impact of investment level variable on the infrastructure factor at the Kingdom of Saudi Arabia.

- To identify the impact of investment age variable on the legislations and regulations related to investment at the Kingdom of Saudi Arabia.

- Investigate the impact of the investment field variable on qualified human forces at the Kingdom of Saudi Arabia.

- Draw the conclusions and provide the recommendations that may benefit the decision-makers.

\section{Study Hypotheses}

The study is based on the following main hypothesis:

"There is no statistically significant relationship at the level $(\alpha \leq$ 0.05 ) for E-Commerce on motivating the investment at the Kingdom of Saudi Arabia”. This was divided into the following two sub-hypotheses:

First sub-hypothesis: there is a statistically significant relationship at level $(\alpha \leq 0.05)$ of E-Commerce on the investment at the Kingdom of Saudi Arabia, due to the independent variables (infrastructure, regulations and legislations, manpower).

Second sub-hypothesis: there is no statistically significant relationship at level $(\alpha \leq 0.05)$ of E-Commerce on the investment at the Kingdom of Saudi Arabia, due to the demographic variables (age, gender, educational level).

\section{Study Questions}

What is the impact of E-Commerce (regulations and legislations, infrastructure, workforce) on motivating the investment in the Kingdom of Saudi Arabia? To answer this main question, the following sub-questions must be answered: 
- What is the impact of the sex variable of sample members on investment at the Kingdom of Saudi Arabia?

- What is the impact of the age variable of sample members on investment in the Kingdom of Saudi Arabia?

What is the impact of a scientific level variable of sample members on investment at the Kingdom of Saudi Arabia?

What is the impact of the investment level variable on the infrastructure factor at the Kingdom of Saudi Arabia?

What is the impact of investment age variable on the legislations and regulations related to investment at the Kingdom of Saudi Arabia?

What is the impact of the investment field variable on the qualified human force at the Kingdom of Saudi Arabia?

\section{Study Model}

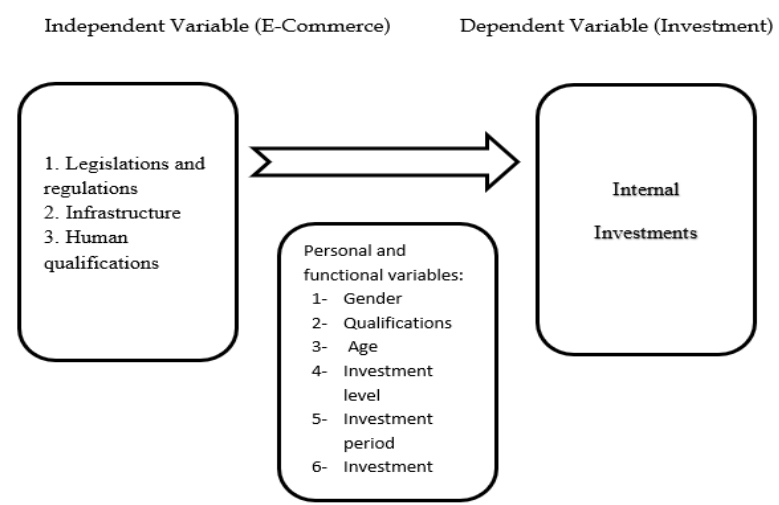

Figure 1: Study model

\section{Study Limitations}

The study was limited to the owners of electronic stores in the Kingdom of Saudi Arabia pertaining to various categories (small, medium, large). The study was limited to measuring three major variables related to motivating the investment in the Kingdom of Saudi Arabia (regulations and legislations, infrastructure, manpower).

\section{Theoretical Framework and Previous Studies \\ 9.1 Theoretical Framework}

E-commerce is defined as a purchasing and selling process between consumers and producers or between companies using information and communication technology (ICT) (Radwan, 1999). It is known as a system that allows the online sale and purchase transactions of goods, services, and information as well as electronic transactions that support generating revenues, such as enhancing the demands of those goods, services, and information. E-Commerce supports sales and customers' service processes via the Internet (Hammad, 2003). U.S. government documents on E-Commerce have identified it as the best use of all types of available communication technologies to develop the commercial activity of projects (Ghonim, 2002). We find ECommerce to be comprised of two parts: first, it refers to the commercial activity that of trading goods and services in accordance with agreed rules and systems. Second, it relates to electronic performing of economic and commercial activities through the use of modern communications technology, such as the Internet and other electronic methods and networks (Bassioni, 2003). Literature overview provides many definitions of E-commerce. E-Commerce is an integrated set of operations, such as production, distribution, marketing, and sale of products using electronic media. It's commerce or trade due to the fact that it involves an exchange of goods and services for money, and most or all of the transactions are conducted through an electronic means via the Internet (Hammad, 2003).

The invention of the Internet prompted a revolution that has allowed new levels of advancement and facilitated the creation of new opportunities for individuals, companies, and governments. This was previously not the case in the economy. Internet-enabled low cost of marketing the product electronically in comparison with the previous traditional methods, where the marketing relied on the traditional media, such as television, newspapers, and magazines are very expensive and temporary, unlike the Internet. The Internet also provides an opportunity to market the product globally and not just locally, with different languages and distinctive designs that attract the attention of customers at very small costs. In addition, there are no longer any restrictions on commerce, such as licenses, offices, agents, and other complex and costly procedures (Qandeelji, 2015).

With the creation of smart applications for E-Commerce, new classifications or categories have emerged for organizations and institutions utilizing digital technology when conducting transactions. These include service producers, software and programmers (servers, input and output control), and distributors and customer services (Ghonim, 2002). As a result, new classifications for commercial organizations and institutions have emerged. Pure traditional trade includes traditional organizations using the pure physical method of production, marketing, and distribution. The semi-e-commerce consists of organizations that adopt some E-Commerce applications at one stage of production, marketing, and distribution; and the pure E-Commerce and includes the virtual E-Commerce organizations, where all operations like production, marketing, distribution, and payment will be done electronically (Al-Taie, 2010).

Many classifications were developed for E-Commerce, but the most common are those depending on the type of participants or contractual parties, and on the location and goal of electronic exchange. Hammad (2003) classifies E-Commerce into the following types:

a. Business to Consumer (B2C): Organizations, companies, and distributors will provide here the services of marketing, sales, and product support to the consumer electronically. 
b. Consumer to Business ( $\mathrm{C} 2 \mathrm{~B})$ : Consumers, as individuals or groups here, will contact enterprises electronically in order to obtain discounts, facilities, or special product services to achieve competitive earnings or privileges.

c. Business to Business (B2B): The large enterprises here will do business together in order to achieve integration in services. This type occupies the largest volume of electronic transactions in the field of E-Commerce.

d. Consumer to Consumer (C2C): This type of E-Commerce is characterized by the simplicity, where one party offers a commodity or provides service to the public, and another party will purchase this commodity or service electronically and directly from the other party without mediation.

e. Government to Government (G2G): E-commerce between countries is regulated through agreements constituting international trade agreements and rules and may be in the form of bilateral agreements or collective agreements to serve the interests of those countries.

E-commerce reduces the prices of goods to citizens, and as a result, it reflects their purchasing power and their standard of living. It also contributes to the restructuring of wages and markets in general, whereby all of the production, organizational, and managerial structures change. Since the size of E-Commerce and the short life of product creates faster recycling of products and the financial flows associated with it, it leads to profits increase that results from increased sales and exports (Jibreal, 2012). The economy is the backbone of the state based on several key features. The most important of those is the investment, which represents the strength of the state to attract the investors and develop resources in a manner supporting the sustainable development and contributing to the creation of opportunities for young people, and the development of their skills and capabilities. Investment is also contributing to the motivation of competition by increasing the formation and development of wealth on the state and individual level (AlZain, 2012).

Investment refers to using money as financial and physical assets to acquire a return on these assets. The investment comes in two forms: a direct investment that exists in the capital or tangible assets, and indirect financial investment that exists in the financial assets (Al-Hadi, 2015). (Al-Obaidi, 2012) defined it as "the deductible part of income that used to create new production capacities, whether it was physical or human, where the investor bears a margin of risk." Investment is also known as "the process of converting a person's public and non-working funds into other assets (Al-Maghribi, 2011).

The investment depends on the availability of infrastructure, which leads countries to provide it in order to attract more investments and have reflections on the sustainability of deducted capital for the purposes of future investment. This applies to the investment in manpower, since the availability of qualified competencies and manpower consider attractive to foreign investment (Al-Hadi, 2015). Countries that are poor in its economic resources have been able to position themselves on the list of industrialized and rich countries, due to the successful domestic and foreign investments which needs a good short and long term planning, and needs to enact legislation that protects and motivates investment, and directs it to the different sectors and achieve the comprehensive and sustainable growth in various sectors of the country.

Kingdom of Saudi Arabia considers one of the most portability countries in the region to attract investments since it enjoys political stability, economic development, and availability of resources and manpower but the foreign and domestic investments have not been at the desired level and have gone through many fluctuations (Muhannad and Turki, 2013). The investment works to localize new sectors in the country that was not available previously, which allows it in the future to develop these sectors and become a key pillar in the economy (Zain, 2012). E-Commerce contributes to easy access of customers to the markets which they wish to purchase from. Therefore, the size of exports to the countries that have superiority in the ECommerce field is constantly increasing within an increase in its revenues. We won't be surprised if the annual profits of an ECommerce company, such as Ali Baba of China equal to the budget of a group of countries or its gross national product, where this sector represents $60 \%$ of the total world production (Jibreal, 2012).

E-Commerce has witnessed several developments in the last decade but the kingdom's shift towards E-Commerce and growing interest in it; on the individuals and government level has become noticeable in the last five years, where the number of Internet users for sale and purchase purposes has increased significantly and steadily with the growing number of new advertisements and government acquisitions processes, according to the report of Saudi Telecommunications and Information Technology Authority (Al-Qahtani, 2004). In 2017, the report of United Nations Trade and Development Conference (UNTDC) specified four criteria to evaluate the countries' readiness to enter the field of E-Commerce: The Internet use, secure computer servers per million people, bank penetration, and mail reliability, which all are critical standards for the growth of E-Commerce inside the country. According to the report, Saudi Arabia ranks 46th out of 144 countries with a 69-degree index, as its equal to some European countries and it's also better than some countries, such as India and China. It noticed that Kingdom's performance in internet use improved; in terms of the penetration between 2009 and 2016 from 64 to 74 and the mail reliability from 69 to 75 , with the possibility that Kingdom could exceed those figures by increasing the reliability of banks and credit cards, and improving the number of secure Internet servers per million people (UNTDC Report, 2017). 
Saudi Arabia considers one of the largest markets in the Middle East; in terms of purchasing and selling online where it represents one of the top 10 growing countries in the ECommerce field in the world, where it increased by $32 \%$ to 80 billion riyals in 2018 , online shopping rose to $49.9 \%$, and the average per capita expenditure for online shopping reached 4,000 riyals (Al-Jadran, 2019). The Kingdom works hard in all its relevant sectors to keep pace with vision 2030 toward converting the retail sector from traditional trade into ECommerce, where the Kingdom recently made extensive changes to the investment system to provide a competitive Saudi economy which is one of the basic principles of Kingdom's Vision 2030 that gives foreign investors the treatment of local investors (Saudi Investment Promotion System, 2019).

In spite of the weakness of E-Commerce in developing countries but it has unlimited potentials for the Arab youth and especially for the Saudi, with the tools and capabilities they own that make them an effective and workforce on the local and global level. This will happen in case of achieving the Kingdom's vision 2030. Its plans went as it programmed with the government's approach to Scholarship for finding the qualitative competencies in various disciplines, which will make the Kingdom one of the most influential countries in the qualified human resources of multiple fields, but this considerable project requires an investment in the human resources at all sectors, such as education, technology, health, commerce, manufacturing, mining, and any other sectors that create an integration to achieve the macroeconomic renaissance (Arafah, 2009).

In the Kingdom of Saudi Arabia, we find the ideal opportunity for this type of commerce due to the government's relentless efforts to develop this sector and create the right infrastructure; as well as the enactment of legislation to keep pace with this development. Therefore, we find many local, new companies in the various sectors that have emerged and achieved successes, not to mention the major domestic and foreign companies that have headed toward the investment in this field and contribute to the development of national economy, and provide it with the new rules in the field of technology, communications, logistics, and others (Allam, 2010).

\subsection{Previous Studies}

(Al-Jadran, 2019) study that entitled "Saudi Investment System in light of the Kingdom's Vision 2030" aimed to conduct an analytical reading for the documents of new Saudi investment system project for the year 2019, in comparison with the old foreign investment system of 2000 , to arrive at a constructive critical vision that comes up with an assessment for the Saudi investment system that is capable of achieving the Kingdom's Vision 2030. The researcher used the comparative critical analytical descriptive approach, where the investment system principles were categorized simply and concisely to analyze the related regulatory texts and then criticize it in a constructive way by comparing it with the documents of World Bank. The researcher reached several conclusions; the most important is the development of regulatory work clearly from the old foreign investment system in the Kingdom toward additional liberalization of the foreign capital movement, and to invest in it through the new investment system project, which keeps pace with the Kingdom vision 2030. The researcher also found that requested criteria of World Bank to attract the direct foreign investment were higher than the new system project, which moves toward the interest of foreign investors and on the expense of host countries for direct investment.

The study of (Al-Jazar, 2019) which entitled "The qualified incentives and factors for the investment environment in the Arab world based on the best practices" is a study that was published in the Federation of Arab Chambers-Economic Department. The researcher aimed to identify the most important incentives provided by Arab countries to achieve the best investments in voluntary sectors. The researcher used the descriptive-analytical method to analyze the data provided and arrived to several results, the most important indicated that flows of foreign investment in the Arab countries were lower in 2018 than 2017. Still, the year 2019 witnessed a decline in the attractiveness of Arab countries to the foreign investments and also seen a slip in the Arab Group's ranking to the fifth place; out of seven groups.

The study of Saudi Ministry for Commerce and Investment (2017) that entitled "The study of E-Commerce in Saudi Arabia for micro and small organisms" aimed to identify the challenges that face the growth of E-Commerce market in the Kingdom, where the study relied on the descriptive analytical approach through an electronic questionnaire with a sample of (384) members from the owners of electronic stores. The study concluded several results; the most important indicated that government registration procedures are long, complicated, and unclear, and also there are problems in delivery, shipping, and payment, especially with the payment method at the time of receiving the order. Also, the study indicated the absence of a unified database for store owners about customers to help them speed up the delivery of goods, which result in delays and increased costs.

The study of (Al-Khatab, 2016) that entitled "The impact of direct foreign investment on the domestic investment in the Kingdom of Saudi Arabia" aimed to identify the direct foreign investment, its nature, and the most important theories that explained it. The researcher used the descriptive-analytical methods represented in the linear and logarithmic formulas, built standard models by using the simple and multiple linear regressions and tested the results of data analysis with the help of the SPSS program. The researcher reached several conclusions, the most important was obtained from the estimations and analysis of the direct foreign investment impact on domestic investment in the Kingdom of Saudi Arabia, where most of the estimated model complements the moral impact of 
direct foreign investment on the domestic investment in Saudi Arabia, and also showed a positive and expulsion relationships. Still, it wasn't at the level of ambition.

The study of (Al-Khalifa, 2015) aimed to examine and analyze the phenomenon of E-Commerce and the reality of Sudanese companies, and address the obstacles of E-Commerce implementation, where the researcher used the descriptiveanalytical method in this study. The study arrived to several results. The most important indicate a statistically significant positive relationship between the use of E-Commerce in the company and the required essential elements for the purpose of E-Commerce. It also concluded a statistically significant negative relationship between the use of E-Commerce in corporate and legal marketing.

A study by (Kriemah, 2014) aimed to shed light on E-Commerce as a new economic concept, where the researcher used the descriptive analytical approach that relies on data collection from the official departments and international reports and analyze it, and also depends on the method of interviewing a number of specialists in the field. The researcher arrived at a number of results. The most important indicated that Algeria doesn't have the necessary infrastructure to keep up and activate the E-Commerce; as a source of motivation for the national economy, due to the unavailability of Broadband internet which are essential for the development of this sector.

The study of HE Yong (2011) aimed to identify the impact of ECommerce on the international trade by using the Eisberg cost calculation model, and the study concluded that E-Commerce has an impact on international trade through production, exports, imports, virtual trade, services, earnings, and other factors.

The differences between this study and the previous studies:

This study distinguished from other studies in terms of the study variables (infrastructure, regulations and legislations, manpower), where the researcher didn't find any of the studies that addressed the impact of E-Commerce on the motivation of investment in Saudi Arabia that used these variables. The study also was characterized by the multiplicity of tests conducted by the researcher to analyze and process the data and produces the most accurate results. The researcher also sought in this study to address the maximum possible issues that face the investment through E-Commerce by listing it in the questionnaire items.

\section{Study Methodology and Procedures 10.1 Study Methodology}

The study adopted the descriptive-analytical method, after returning to the different previous studies and literature which are related to the study topic like books and articles to prepare the theoretical aspect. The researcher also visited a group of electronic stores with its various categories (small, medium, large) in Saudi Arabia to learn about the nature of its work. The questionnaire; as a data collection tool was distributed on investors at the online stores to obtain responses on its questions, and then use the analytical method to analyze the variables and reach the possible conclusions statistically.

\subsection{Study Procedures}

Study Population: the study society consists of investors in electronic stores with its different classifications (small, medium, large) which are registered in Saudi Arabia.

Sample size: The random sample method was adopted by distributing the questionnaire on (250) investors and the number of respondents were (202) investors with $81 \%$ which consider an acceptable ratio for this study.

Tool Validity: to obtain the primary data and information for this study, a questionnaire was designed to study (the impact of E-Commerce on motivating the investment in Saudi Arabia), which is a well-known method for collecting the field information and characterized by the ability to receive information from multiple terms of the study sample and analyze it to reach the specific results.

Researchers followed the following steps during the study tool building process:

- Researchers returned to the previous literature related to the study topic to see what has been written about E-Commerce and investment motivation.

- Researchers presented the study tool in its initial form on a group of specialists as arbitrators, where they were asked to express their opinions and make their judgments on the performance; in terms of the reliability level of items with the research hypotheses.

- In light of arbitrators' remarks, the following modifications were performed:

- Delete the paragraphs that they suggested to delete.

- Adjust and redraft some items to give their intended meaning.

The questionnaire was prepared in its final form, which consisted of five sections and included the general and personal data while the questionnaire questions consisted of 40 items that are divided into four dimensions, three of it dealt with the independent variable which is E-Commerce and includes (infrastructure, regulations and legislation, workforce). The fourth dimension addressed the dependent variable (investment).

These sections include:

First section: includes six multiple-choice questions that measure the demographic characteristics and the characteristics of respondents, and include (sex, age, educational level, level of investment, investment age, investment field). 
Second section: includes seven items that deal with the infrastructure topic in the E-Commerce variable.

Third section: includes eight items that deal with the regulations and legislations topic in the E-Commerce variable.

Forth section: includes ten items that deal with the workforce topic in the E-Commerce variable.

Fifth section: includes fifteen items that deal with the investment variable.

Internal reliability \& consistency tests of the used measurements (data credibility level)

The reliability of measurements means the error-free measurements level or the degree of internal consistency between the different phrases that measure a variable, and the reliability means stability, or to obtain the same values whenever the measuring instrument is used, and therefore it will lead to the same results or consistent results every time the measurement is repeated. The greater the reliability and stability of the tool, the greater the confidence in it, and to test the availability level of reliability and internal consistency between the responses to the questions, the Cronbach Alpha Coefficient credibility was calculated, where the statistically acceptable value for the Cronbach Alpha Coefficient is (60\%) (Sekaran, U \& Bougie, 2010), and the credibility test was conducted on the responses of respondents.

To confirm the reliability of measurement tool that used in the study, the Cronbach Alpha Coefficient was calculated for the study dimensions, and table (1) shows the Alpha values of study dimensions; as follows:

Table 1: Cronbach Alpha Coefficient of Internal Consistency

\begin{tabular}{|c|c|}
\hline Dimensions & Internal Consistency \\
\hline Infrastructure & 0.76 \\
\hline Regulations and legislations & 0.71 \\
\hline Manpower & 0.74 \\
\hline $\begin{array}{c}\text { Dependent factor as a } \\
\text { whole }\end{array}$ & 0.81 \\
\hline Investment & 0.70 \\
\hline
\end{tabular}

Table (1) shows that Cronbach Alpha Coefficient values for internal consistency; for all the dimensions of study tool items (questionnaire) were between (0.71-0.89), where the reliability considered weak if the coefficient values are less than $(0.60)$ as (Sekaran \& Bougie, 2010) assumed that minimum reliability coefficient value is (0.70), and also the reliability considers good whenever the coefficient value is $(0.80)$ or more, therefore the values listed in the previous table consider an indication on the reliability of study tool, the consistency of its items, its dependability, and the possibility of relying on it to conduct the statistical analysis.

\section{Statistical Analysis}

The researchers used many of the statistical analysis methods to process and analyze data; in order to reach the most accurate results according to the following order:

\section{Adoption of the statistical scale}

The Five Likert scales were adopted to correct the study tools, by giving each one of its items a degree out of five (strongly agree, agree, neutral, disagree, and strongly disagree) which are digitally represent $(5,4,3,2,1)$ respectively, and the following scale was adopted for the purposes of analyzing the results:

$1.00-2.33$ few

$2.34-3.67$ medium

3.68 - 5.00 large

Normal Distribution Test (Normality)

Normal distributions of data were confirmed by using the OneSample Kolmogorov-Smirnov test, as shown in table (2):

Table 2: One-Sample Kolmogorov-Smirnov Test for independent variables and the dependent variable

\begin{tabular}{|l|c|c|}
\hline Variables & $\begin{array}{c}\text { One Sample } \\
\text { Kolmogorov- } \\
\text { Smirnov test value }\end{array}$ & Seg \\
\hline Infrastructure & 1.137 & 0.151 \\
\hline $\begin{array}{l}\text { Regulations and } \\
\text { legislations }\end{array}$ & 1.007 & 0.263 \\
\hline Manpower & 1.289 & 0.083 \\
\hline Investment & 0.964 & 0.311 \\
\hline
\end{tabular}

It shows from the table (2) that statistically significant value for the One-Sample Kolmogorov-Smirnov test; for all variables was greater than the significance level $(\alpha \leq 0.05)$, which indicate that variables follow the normal distribution. Furthermore, based on the Central tendency theory which states that if the sample size is greater than (30), has an arithmetic mean $(\mu)$, and a variation $(\sigma 2)$, then the sampling distribution of mean is approaching the normal distribution (Al-Heati, 2004).

Study model suitability test for the used statistical methods

The linear correlation test was used to ensure the non-existence of high correlation between the independent variables, based on the Variance Inflation Factor (VIF) test and the Tolerance test for each one of the independent variables, where the independent variables of the model must be independent among itself and to confirm that this test considers a way to get rid of the linear multiplicity problem, knowing that VIF value must not exceed (10) and the Tolerance test value must be greater than (0.05), 
and after calculating the previous coefficients for all the independent variables, the results show in the following table:

Table 3: VIF and Tolerance test for the study variables

\begin{tabular}{|l|c|c|}
\hline $\begin{array}{l}\text { Independent } \\
\text { variables }\end{array}$ & Tolerance & VIF \\
\hline Infrastructure & 0.480 & 2.083 \\
\hline $\begin{array}{l}\text { Regulations and } \\
\text { legislations }\end{array}$ & 0.515 & 1.941 \\
\hline Manpower & 0.658 & 1.520 \\
\hline
\end{tabular}

Table (3) shows that VIF test values for all variables are less than (10) while the Tolerance test value for all variables is greater than (0.05), and therefore it's possible to say that there are no high correlation problems between the variables and indicates non-existence of statistically significant correlation between the independent variables listed in the correlation table, which enhances the possibility of using it in the model based on (Gujarati, 2004, 352).

The Pearson's Correlation Coefficients between the dimensions of independent variable were used to confirm the previous results and ensure the non-existence of Multiple Linear Correlation between the sub-variables in the independent variable, and the results showed in the following table:

Table 4: Pearson Correlation Matrix between the sub-variables in the independent variable

\begin{tabular}{|l|c|c|c|}
\hline & Infrastructure & $\begin{array}{c}\text { Regulations } \\
\text { and } \\
\text { legislations }\end{array}$ & Manpower \\
\hline Infrastructure & 1 & 1 & \\
\hline $\begin{array}{l}\text { Regulations } \\
\text { and } \\
\text { legislations }\end{array}$ & $0.678 * *$ & & 1 \\
\hline Manpower & $0.557 * *$ & $0.509 * *$ & 1 \\
\hline
\end{tabular}

** Statistically significant at level $(\alpha \leq 0.01)$

Table (4) shows that highest correlation between the subvariables of independent variables is $(0.678)$ between the two variables (regulations and legislations) and (infrastructure), while the correlation coefficient values between other independent variables were lower than that, which indicate the non-existence of high Multiple Linear Correlation between the sub-variables of independent variables where it all came less than (0.80) and therefore the sample is free of the high Multiple Linear correlation problem (Gujarati, 2004, 352).

\section{Data Analysis and Results Discussion \\ 11.1 Statistical Description of the Study Sample According to General Information}

Table 5: Frequencies and percentages according to the study variables

\begin{tabular}{|c|c|c|c|}
\hline 9 & Categories & Frequencies & Percentages \\
\hline \multirow{3}{*}{ Age } & $\begin{array}{l}\text { Between 21- } \\
30 \text { yrs. }\end{array}$ & 72 & 35.6 \\
\hline & $\begin{array}{l}\text { Between 31- } \\
40 \text { yrs. }\end{array}$ & 81 & 40.1 \\
\hline & $\begin{array}{l}41 \text { yrs. \& } \\
\text { higher }\end{array}$ & 49 & 24.3 \\
\hline \multirow{2}{*}{ Gender } & Male & 133 & 65.8 \\
\hline & Female & 69 & 34.2 \\
\hline \multirow{3}{*}{$\begin{array}{l}\text { Educational } \\
\text { Level }\end{array}$} & $\begin{array}{l}\text { Master or } \\
\text { higher }\end{array}$ & 46 & 22.8 \\
\hline & Bachelor & 127 & 62.9 \\
\hline & $\begin{array}{l}\text { High School } \\
\text { or less }\end{array}$ & 29 & 14.4 \\
\hline \multirow{3}{*}{$\begin{array}{l}\text { Investment } \\
\text { Level }\end{array}$} & $\begin{array}{l}\text { Small (less } \\
\text { than } 5 \\
\text { employees) }\end{array}$ & 103 & 51.0 \\
\hline & $\begin{array}{l}\text { Average (5-15 } \\
\text { employees) }\end{array}$ & 67 & 33.2 \\
\hline & $\begin{array}{l}\text { Large (more } \\
\text { than } 15 \\
\text { employees) }\end{array}$ & 32 & 15.8 \\
\hline \multirow{3}{*}{$\begin{array}{l}\text { Investment } \\
\text { Period }\end{array}$} & $\begin{array}{l}\text { Between 1-3 } \\
\text { yrs. }\end{array}$ & 92 & 45.5 \\
\hline & $\begin{array}{l}\text { Between 4-7 } \\
\text { yrs. }\end{array}$ & 76 & 37.6 \\
\hline & $\begin{array}{l}\text { More than } 7 \\
\text { yrs. }\end{array}$ & 34 & 16.8 \\
\hline \multirow{8}{*}{$\begin{array}{l}\text { Investment } \\
\text { Field }\end{array}$} & $\begin{array}{l}\text { Clothing and } \\
\text { accessories }\end{array}$ & 60 & 29.7 \\
\hline & $\begin{array}{l}\text { Electronic } \\
\text { and electrical } \\
\text { devices }\end{array}$ & 38 & 18.8 \\
\hline & $\begin{array}{l}\text { Public } \\
\text { services } \\
\text { (hotels, } \\
\text { tickets, } \\
\text { tourism) }\end{array}$ & 17 & 8.4 \\
\hline & $\begin{array}{l}\text { Stocks and } \\
\text { banks }\end{array}$ & 22 & 10.9 \\
\hline & $\begin{array}{l}\text { Real estate } \\
\text { and } \\
\text { construction } \\
\text { services }\end{array}$ & 32 & 15.8 \\
\hline & $\begin{array}{l}\text { Educational } \\
\text { and training } \\
\text { services }\end{array}$ & 16 & 7.9 \\
\hline & $\begin{array}{l}\text { Vehicles and } \\
\text { auto parts }\end{array}$ & 17 & 8.4 \\
\hline & Total & 202 & 100.0 \\
\hline
\end{tabular}


What is the impact of E-Commerce (regulations and legislations, infrastructure, workforce) on motivating the investment in the Kingdom of Saudi Arabia?

Multiple Linear Regression was used to answer this question, and the results were as follow:

Table 6: Results of the multiple linear regression test for the impact of E-Commerce (regulations and legislations, infrastructure, manpower) on motivating the investment in Saudi Arabia

\begin{tabular}{|c|c|c|c|c|c|c|c|c|c|c|}
\hline \multirow{2}{*}{\begin{tabular}{|l} 
Depende \\
nt \\
Variable
\end{tabular}} & \multicolumn{2}{|c|}{$\begin{array}{c}\text { Model } \\
\text { Summary }\end{array}$} & \multicolumn{3}{|c|}{ ANOVA } & \multicolumn{5}{|c|}{ Coefficient } \\
\hline & R & $\mathrm{R}^{2}$ & F & DF & $\begin{array}{c}\text { Sig. } \\
\mathrm{F}\end{array}$ & Field & B & $\begin{array}{l}\text { Standar } \\
\text { derror }\end{array}$ & $t$ & $\begin{array}{c}\text { Sig. } \\
t\end{array}$ \\
\hline \multirow{3}{*}{$\begin{array}{l}\text { Investme } \\
\text { nt }\end{array}$} & \multirow{3}{*}{0.736} & \multirow{3}{*}{0.542} & \multirow{3}{*}{ 77.996 } & \multirow{3}{*}{3} & \multirow{3}{*}{0.000} & $\begin{array}{l}\text { Infrastructu } \\
\text { re }\end{array}$ & 0.098 & 0.048 & $\begin{array}{c}2.02 \\
5\end{array}$ & $\begin{array}{c}0.04 \\
4 \\
\end{array}$ \\
\hline & & & & & & $\begin{array}{l}\text { Regulations } \\
\& \\
\text { legislations }\end{array}$ & 0.147 & 0.054 & $\begin{array}{c}2.71 \\
6\end{array}$ & $\begin{array}{c}0.00 \\
7\end{array}$ \\
\hline & & & & & & Manpower & 0.480 & 0.054 & $\begin{array}{c}8.83 \\
5\end{array}$ & $\begin{array}{c}0.00 \\
0\end{array}$ \\
\hline
\end{tabular}

The results indicate a statistically significant impact of ECommerce on motivating investment, where the correlation coefficient amounted to $(\mathrm{R}=0.736)$ which refers to the existence of a statistically significant correlation between the independent variables (Regulations \& legislations, infrastructure, manpower); as a whole on motivating the investment. It shows that the selection coefficient value is $(\mathrm{R} 2=0.542)$, which indicates that E-Commerce explains $54.2 \%$ of the variation that occurs in investment motivation. At the same time, the remaining goes back to other variables that didn't take part in the model. The value of $(\mathrm{F}=77.996)$ reached a confidence level of $(\mathrm{sig}=0.000)$ and this confirms the regression significance at the level $(\alpha \leq 0.05)$.

It shows from the correlation coefficient table that (B) values at the dimension infrastructure reached (0.098), and that t-value was (2.025) at a statistically significant of (0.044), which indicates that the impact of this dimension is significant and means that any increase in the independent by one unit will lead to an increase in investment motivation by $(0.098)$.

It shows from the correlation coefficient table that (B) values at the dimension Regulations \& legislations reached (0.147), and that t-value was (2.716) at a statistically significant of (0.007), which indicates that the impact of this dimension is significant and means that any increase in the independent by one unit will lead to an increase in investment motivation by (0.147). It shows from the correlation coefficient table that (B) values at the dimension manpower reached (0.480) and that t-value was (8.835) at a statistically significant of (0.000), which indicates that the impact of this dimension is significant and means that any increase in the independent by one unit will lead to an increase in investment motivation by $(0.480)$. To discuss the results of this question, it's necessary to consider all the dimensions and items of the independent variable in detail, as well as the items of the dependent variable as follows:

Dimensions of the Independent Variable: E-Commerce: the arithmetic means and standard deviations of the study sample responses about E-Commerce were calculated, and the results as follow:

\section{Infrastructure}

Table 7: Arithmetic means and standard deviations of items related to the infrastructure

\begin{tabular}{|c|l|c|c|c|c|}
\hline $\begin{array}{c}\text { Num } \\
\text { ber }\end{array}$ & \multicolumn{1}{|c|}{ Items } & $\begin{array}{c}\text { Mea } \\
\mathrm{n}\end{array}$ & $\begin{array}{c}\text { STDE } \\
\mathrm{V}\end{array}$ & $\begin{array}{c}\text { Ran } \\
\mathrm{k}\end{array}$ & $\begin{array}{c}\text { Materia } \\
\text { lity }\end{array}$ \\
\hline 7 & $\begin{array}{l}\text { Customer evaluations give businesses the } \\
\text { opportunities to develop and improve its } \\
\text { quality }\end{array}$ & 4.49 & 0.663 & 1 & High \\
\hline 1 & $\begin{array}{l}\text { E-Commerce offers opportunities better } \\
\text { than traditional trade }\end{array}$ & 4.44 & 0.668 & 2 & High \\
\hline 4 & $\begin{array}{l}\text { Consumer selections are large in the online } \\
\text { store }\end{array}$ & 4.26 & 0.848 & 3 & High \\
\hline 2 & $\begin{array}{l}\text { E-Store earnings are better than the } \\
\text { traditional trade earnings }\end{array}$ & 4.24 & 0.800 & 4 & High \\
\hline 6 & $\begin{array}{l}\text { Payment methods of online store are better } \\
\text { than the traditional stores }\end{array}$ & 4.18 & 0.778 & 5 & High \\
\hline 5 & $\begin{array}{l}\text { Prices in the online store are lower than } \\
\text { traditional store }\end{array}$ & 4.16 & 0.863 & 6 & High \\
\hline 3 & $\begin{array}{l}\text { The risks of E-Commerce are lower than } \\
\text { traditional trade }\end{array}$ & 3.99 & 0.930 & 7 & High \\
\hline & \multicolumn{1}{|c|}{ Infrastructure } & 3.70 & 0.522 & & High \\
\hline
\end{tabular}

It shows from the table (7) that relative importance or materiality of infrastructure items came high, where the total arithmetic mean amounted to (3.70) with a standard deviation of (0.522). The item that states:

"Customer evaluations give businesses the opportunities to develop and improve its quality" came at first place among the items with an arithmetic mean of (4.49), a standard deviation of (0.663), and high materiality due to increased consumer awareness and their directions toward the electronic companies that care about the opinions and evaluations of customers, to develop its performance and build bridges of trust and transparency between these companies and customers. It also considers an attraction for new customers who look for guaranteed and highly valued companies.

While the item that states "The risks of E-Commerce are lower than traditional trade" came at last place among the items with an arithmetic mean of (3.99), a standard deviation of (0.930), and high materiality, because E-Commerce companies don't bear unexpected additional costs on the goods, the product's life cycle is shorter in the traditional trade with fewer risks, and also the large companies insure the goods at all stages; such as purchasing, transporting, supplying, and distributing while the traditional stores bear many risks of goods' damage or being exposed to storage risks and market fluctuations; in terms of 
maintaining its cash values as a result of market fluctuations and exchange rates. This result agrees with the study of (Khalifa, 2015) that there is a statistically positive significant relationship between the use of E-Commerce in the company and the required basic essentials of infrastructure configuration.

\section{Regulations and Legislations}

Table 8: Arithmetic means and standard deviations of items related to the regulations \& legislations

\begin{tabular}{|c|l|c|c|c|c|}
\hline $\begin{array}{c}\text { Numb } \\
\text { er }\end{array}$ & \multicolumn{1}{|c|}{ Items } & $\begin{array}{c}\text { Mea } \\
\mathrm{n}\end{array}$ & $\begin{array}{c}\text { STDE } \\
\mathrm{V}\end{array}$ & $\begin{array}{c}\text { Ran } \\
\mathrm{k}\end{array}$ & $\begin{array}{c}\text { Materiali } \\
\text { ty }\end{array}$ \\
\hline 8 & $\begin{array}{l}\text { Electronic stores allow the comparison of } \\
\text { prices and specifications of a product }\end{array}$ & 4.36 & 0.708 & 1 & High \\
\hline 16 & $\begin{array}{l}\text { Regulations \& legislations in the } \\
\text { Kingdom encourage E-Commerce }\end{array}$ & 4.18 & 0.754 & 2 & High \\
\hline 11 & $\begin{array}{l}\text { Returning the product is easier in the } \\
\text { traditional stores }\end{array}$ & 3.89 & 0.902 & 3 & High \\
\hline 12 & $\begin{array}{l}\text { Possibility of fraud and cheating is larger } \\
\text { at the online store }\end{array}$ & 3.88 & 1.012 & 4 & High \\
\hline 9 & $\begin{array}{l}\text { The contracting system in traditional } \\
\text { trade is better than electronic contracting }\end{array}$ & 3.79 & 1.030 & 5 & High \\
\hline 14 & $\begin{array}{l}\text { E-Commerce offers more jobs than } \\
\text { traditional trade }\end{array}$ & 3.75 & 1.056 & 6 & High \\
\hline 10 & $\begin{array}{l}\text { The quality and suitability of product is } \\
\text { higher in the traditional store }\end{array}$ & 3.58 & 1.058 & 7 & High \\
\hline 15 & $\begin{array}{l}\text { Creating E-Commerce requires numerous } \\
\text { and complex procedures }\end{array}$ & 3.16 & 1.215 & 8 & Medium \\
\hline 13 & $\begin{array}{l}\text { E-Commerce requires more capital than } \\
\text { the traditional }\end{array}$ & 3.12 & 1.174 & 9 & Medium \\
\hline & \multicolumn{1}{|c|}{ Regulations \& legislations } & 3.90 & 0.450 & & High \\
\hline
\end{tabular}

It shows from table (8) that the materiality of the regulations \& legislations' items came high, where the total arithmetic mean amounted to (3.90) with a standard deviation of (0.450). The item that states: "Electronic stores allow the comparison of prices and specifications of a product" came at first place among the items with an arithmetic mean of (4.36), a standard deviation of (0.708), and high materiality while the item that states: "ECommerce requires more capital than the traditional" came at the last place among items with an arithmetic mean of (3.12), a standard deviation of (1.174), and medium materiality. Also, the item that states:

"Creating E-Commerce requires numerous and complex procedures" came at the place before last among items with an arithmetic mean of (3.16), a standard deviation of (1.215), and medium materiality, which agree with the study of (Khalifa, 2015) that there is a statistically significant negative relationship between the use of E-Commerce in companies and the legal marketing, where the companies of E-Commerce tend to avoid legal procedures for fear of taxes and prosecution, and agree with the study results of (Saudi Ministry of Trade and Investment, 2017), that government registration procedures are long, complex, and unclear.

\section{Manpower}

Table 9: Arithmetic means and standard deviations of items related to manpower

\begin{tabular}{|c|l|c|c|c|c|}
\hline $\begin{array}{c}\text { Num } \\
\text { ber }\end{array}$ & \multicolumn{1}{|c|}{ Items } & $\begin{array}{c}\text { Mea } \\
\mathrm{n}\end{array}$ & $\begin{array}{c}\text { STDE } \\
\mathrm{V}\end{array}$ & $\begin{array}{c}\text { Ran } \\
\mathrm{k}\end{array}$ & $\begin{array}{c}\text { Materia } \\
\text { lity }\end{array}$ \\
\hline 20 & $\begin{array}{l}\text { E-Commerce needs professional media } \\
\text { advertising more than traditional stores to } \\
\text { be known }\end{array}$ & 4.26 & 0.762 & 1 & High \\
\hline 24 & $\begin{array}{l}\text { Attracting customers in E-Commerce is } \\
\text { easier than traditional trade }\end{array}$ & 4.18 & 0.835 & 2 & High \\
\hline 25 & $\begin{array}{l}\text { Competition in E-Commerce is higher than } \\
\text { traditional trade }\end{array}$ & 4.11 & 0.880 & 3 & High \\
\hline 23 & $\begin{array}{l}\text { Inventory management requires less effort } \\
\text { in E-Commerce than traditional trade }\end{array}$ & 4.09 & 0.793 & 4 & High \\
\hline 19 & $\begin{array}{l}\text { E-Commerce requires documentation } \\
\text { through many of the official channels }\end{array}$ & 3.99 & 0.719 & 5 & High \\
\hline 18 & $\begin{array}{l}\text { E-Commerce requires specialists more than } \\
\text { the traditional trade }\end{array}$ & 3.89 & 0.888 & 6 & High \\
\hline 21 & $\begin{array}{l}\text { Purchasing, selling, and delivery processes } \\
\text { in E-Commerce require greater efforts than } \\
\text { traditional trade }\end{array}$ & 3.88 & 1.025 & 7 & High \\
\hline 22 & $\begin{array}{l}\text { Litigation procedures and claiming rights in } \\
\text { E-Commerce are easier than in traditional } \\
\text { trade }\end{array}$ & 3.65 & 0.972 & 8 & Mediu \\
\hline 17 & $\begin{array}{l}\text { E-Commerce requires a huge and expensive } \\
\text { infrastructure and wages of employees }\end{array}$ & 3.04 & 1.184 & 9 & Mediu \\
\hline & \multicolumn{1}{|c|}{ Manpower } & 4.07 & 0.396 & & High \\
\hline
\end{tabular}

It shows from the table (9) that materiality for the items of manpower came high, where the total arithmetic mean amounted to (4.07) with a standard deviation of (.396). The item that states: "E-Commerce needs professional media advertising more than traditional stores to be known" came in the first place among the items with an arithmetic mean of (4.26), a standard deviation of (0.762), and high materiality, which agree with the study of Kareima (2014) that lack of infrastructure, such as qualified manpower could be a reason for E-Commerce to not enter the international market, and that any access to the international market requires experts in the E-Commerce, and also financial and media experts who are capable of marketing their companies globally. While the item that states:

"E-Commerce requires a huge and expensive infrastructure and wages of employees" came in the last place among the items with an arithmetic mean of (3.04), a standard deviation of (1.184), and medium materiality. Researchers attributed that to the fact that most companies are not legally registered. Most owners of electronic stores perform their works by themselves with a reduction in the labour force and employees to a minimum and instead employ a large number of workers with a profit rate and without being committed to pay them a fixed salary, unlike the traditional stores which are committed to hiring employees with a fixed salary, where their numbers vary according to the firm's size. 


\section{Variable: Investment}

Table 10: Arithmetic means and standard deviations of items related to investment, as a dependent variable

\begin{tabular}{|c|l|c|c|c|c|}
\hline Number & \multicolumn{1}{|c|}{ Items } & Mean & STDEV & Rank & Materiality \\
\hline 35 & $\begin{array}{l}\text { The availability of delivery } \\
\text { companies motivates E- } \\
\text { Investment }\end{array}$ & 4.39 & 0.647 & 1 & High \\
\hline 32 & $\begin{array}{l}\text { Increasing numbers of E-Stores } \\
\text { visitors attract the investment in a } \\
\text { variety of areas }\end{array}$ & 4.32 & 0.654 & 2 & High \\
\hline 38 & $\begin{array}{l}\text { Identifying the market } \\
\text { requirements and response to it } \\
\text { quickly motivates the investment } \\
\text { in E-Commerce field }\end{array}$ & 4.30 & 0.655 & 3 & High \\
\hline 36 & $\begin{array}{l}\text { Easy access to the global markets } \\
\text { motivates investment in the field } \\
\text { of international E-Commerce }\end{array}$ & 4.28 & 0.656 & 4 & High \\
\hline 39 & $\begin{array}{l}\text { Availability of a huge database for } \\
\text { the E-Businesses about the desires } \\
\text { and trends of its customers } \\
\text { stimulates the expansion and } \\
\text { growth of E-Commerce }\end{array}$ & 4.23 & 0.662 & 5 & High \\
\hline 31 & $\begin{array}{l}\text { The trust of Saudi citizens in the } \\
\text { various payment methods of E- } \\
\text { Commerce }\end{array}$ & 4.10 & 0.769 & 6 & High \\
\hline 37 & $\begin{array}{l}\text { Banking systems and its flexibility } \\
\text { with the global markets motivate } \\
\text { the investors of E-Commerce }\end{array}$ & 4.10 & 0.729 & 7 & High \\
\hline 26 & $\begin{array}{l}\text { Availability of regulations and } \\
\text { legislations protect investors } \\
\text { adequately in E-Commerce }\end{array}$ & 4.06 & 0.744 & 8 & High \\
\hline 30 & $\begin{array}{l}\text { Saudi citizen's income level } \\
\text { motivates the investment in E- } \\
\text { Commerce }\end{array}$ & 4.04 & 0.728 & 9 & High \\
\hline 34 & $\begin{array}{l}\text { E-Commerce doesn't need a huge } \\
\text { capital to establish it }\end{array}$ & 3.94 & 0.829 & 10 & High \\
\hline 28 & $\begin{array}{l}\text { Availability of infrastructure for E- } \\
\text { Commerce development - } \\
\text { sufficient Internet }\end{array}$ & 3.91 & 0.802 & 11 & High \\
\hline 29 & $\begin{array}{l}\text { Lack of the qualified human } \\
\text { resources create an obstacle for the } \\
\text { investment in E-Commerce }\end{array}$ & 3.84 & 0.872 & 12 & High \\
\hline $\begin{array}{l}\text { Saudi citizens' fear of revealing } \\
\text { their data and accounts slows the } \\
\text { pace of investment in the E- } \\
\text { Commerce field }\end{array}$ & $\begin{array}{l}\text { The domination of traditional } \\
\text { shopping style of women } \\
\text { motivates the traditional trade }\end{array}$ & 3.78 & 0.985 & 13 & High \\
Taxes and customs procedures are & 3.45 & 1.060 & 15 & Medium \\
\hline & 4.08 & 0.363 & & High \\
\hline
\end{tabular}

It shows from table (10) that materiality of investment items came high, where the total arithmetic mean amounted to (4.08) with a standard deviation of (0.363). The item that states: "The availability of delivery companies motivates E-Investment" came at first place among the items with an arithmetic mean of (4.39), a standard deviation of (0.647), and high materiality. While the study of (Saudi Ministry of Commerce, 2017) showed in its results problems in delivery, shipping, and payment, and also found unavailability of a unified database for shopkeepers about the customers that help them in the speed of delivering goods, which lead to delays and increased costs. This requires additional studies that specialize in studying the effectiveness of delivery companies and providing joint databases that facilitate the delivery processes, increase its effectiveness, and reduce the costs on the state level. The item that states: "Taxes and customs procedures are in favour of traditional trade" came at last place among the items with an arithmetic mean of (3.45), a standard deviation of (1.060), and medium materiality, which is since Saudi Arabia's directions in light of Vision 2030 aim to transform the retail sector into E-Commerce and facilitate this transformation through legislation and customs regulations. Despite the state's efforts to establish an institutional organization for E-Commerce, the Kingdom has not yet reached the desired investment size; in this sector according to Vision 2030, and this agrees with the study results of Al-Jazar \& AlJadran (2019) that investments size in the various sectors declined in the Arab countries in 2018, due to the decline in the attractiveness of investment in the Arab group and its decline to the fifth place out of seven groups.

- What is the impact of gender variable on the direction of the sample members to invest in the Kingdom of Saudi Arabia?

To answer this question, the arithmetic means and standard deviations of investment in Saudi Arabia were calculated according to the gender variable, and to show the statistical differences between the arithmetic means the "T" test was used. The following table shows the results:

Table 11: Arithmetic means, standard deviations, and "T" test for the impact of gender on investment in Saudi Arabia

\begin{tabular}{|l|l|c|c|c|c|c|c|}
\hline & & $\begin{array}{c}\text { Numb } \\
\text { er }\end{array}$ & $\begin{array}{c}\text { Mea } \\
\mathrm{n}\end{array}$ & $\begin{array}{c}\text { STDE } \\
\text { V }\end{array}$ & $\begin{array}{c}\text { T- } \\
\text { valu } \\
\mathrm{e}\end{array}$ & $\begin{array}{c}\text { D } \\
\mathrm{F}\end{array}$ & Sig \\
\hline \multirow{4}{*}{$\begin{array}{l}\text { Investme } \\
\mathrm{nt}\end{array}$} & Male & 133 & 4.07 & 0.369 & $\begin{array}{c}- \\
0.89 \\
6\end{array}$ & $\begin{array}{c}20 \\
0\end{array}$ & $\begin{array}{c}0.37 \\
1\end{array}$ \\
\cline { 2 - 8 } & $\begin{array}{l}\text { Fema } \\
\text { le }\end{array}$ & 69 & 4.11 & 0.352 & & & \\
\hline
\end{tabular}

It shows from table (11) non-existence of statistically significant differences at level $(\alpha \leq 0.05)$, due to the impact of sex and the researchers attribute that to E-Commerce in Saudi Arabia which has opened up a wide horizon for Saudi women in general and businesswomen in particular to enter this sector, and also the social restrictions that were preventing women from working in commerce are no longer exist with the time E-Commerce began to flourish in the Kingdom, where women found an opportunity in E-Commerce better than other fields, and due to the fact that this type of trade isn't determined by a specific field or commodity, but it extends to cover the areas of public and consumers interest. In addition, the Internet and social media have facilitated consumers' access regardless of the gender of the service provider.

- What is the impact of age variable on the direction of sample members to invest in the Kingdom of Saudi Arabia?

Table 12: Dimensional comparisons of Scheffe Method for the impact of age on investment in Saudi Arabia

\begin{tabular}{|l|c|c|c|c|}
\hline & Mean & $\begin{array}{c}\text { Between } \\
21-30 \text { yrs. }\end{array}$ & $\begin{array}{c}\text { Between } \\
31-40 \text { yrs. }\end{array}$ & $\begin{array}{c}41 \mathrm{yrs} \text { and } \\
\text { more }\end{array}$ \\
\hline $\begin{array}{l}\text { Between } \\
21-30 \text { yrs. }\end{array}$ & 4.10 & & & \\
\hline $\begin{array}{l}\text { Between } \\
31-40 \text { yrs. }\end{array}$ & 4.14 & 0.04 & & \\
\hline $\begin{array}{l}41 \text { yrs and } \\
\text { more }\end{array}$ & 3.97 & 0.13 & $0.16^{*}$ & \\
\hline
\end{tabular}

* Significant at level $(\alpha \leq 0.05)$ 
It shows from the table (12) the existence of statistically significant differences at level $(\alpha \leq 0.05)$, according to the age groups of investors in E-Commerce, where the differences came in favour of the group (31-40) and the researcher attributed it to the fact that most Youth of university graduates prefer to enter the labour market rather than to wait for jobs, and most of them go toward the E-Commerce sector since it doesn't require huge capital or infrastructure.

- What is the impact of education level variable on the direction of sample, members to invest in the Kingdom of Saudi Arabia?

Table 13: One-Way ANOVA for the impact of educational level on investment in Saudi Arabia

\begin{tabular}{|l|c|c|c|c|c|}
\hline Source & SS & DF & MS & $\begin{array}{c}\text { F- } \\
\text { value }\end{array}$ & Seg \\
\hline $\begin{array}{l}\text { Between } \\
\text { groups }\end{array}$ & 0.223 & 2 & 0.111 & 0.844 & 0.431 \\
\hline $\begin{array}{l}\text { Inside } \\
\text { groups }\end{array}$ & 26.273 & 199 & 0.132 & & \\
\hline Overall & 26.496 & 201 & & & \\
\hline
\end{tabular}

It shows from table (13) non-existence of statistically significant differences at level $(\alpha=0.05)$, due to the scientific level where the researcher attributed it to the fact that E-Commerce doesn't need specialization in the same amount that needs acquired skills from the experiences that individuals go through during the practice of this activity. On the local level, the investor in the field of E-Commerce may need people specialized in some areas but doesn't require it the rest of the crew.

- What is the impact of the investment level variable on the infrastructure factor in Saudi Arabia?

Table 14: One-Way ANOVA for the impact of investment level on the infrastructure factor in Saudi Arabia

\begin{tabular}{|l|c|c|c|c|c|}
\hline Source & SS & DF & MS & $\begin{array}{c}\text { F- } \\
\text { value }\end{array}$ & Seg \\
\hline $\begin{array}{l}\text { Between } \\
\text { groups }\end{array}$ & 0.436 & 2 & 0.232 & 0.850 & 0.429 \\
\hline $\begin{array}{l}\text { Inside } \\
\text { groups }\end{array}$ & 54.279 & 199 & 0.273 & & \\
\hline Overall & 54.742 & 201 & & & \\
\hline
\end{tabular}

It shows from table (14) non-existence of statistically significant differences at level $(\alpha \leq 0.05)$, due to the investment level and this attributed to the fact that most investors in E-Commerce are the owners of small and medium-sized investment, and this agree with the study results of Ministry of Commerce and Investment (2017) where it showed that $73 \%$ of electronic stores' owners don't have a headquarters for their businesses, as they work from home.
- What is the impact of the investment period variable on the legislations and regulations related to investment in Saudi Arabia?

Table 15: One-Way ANOVA for the impact of the investment period on the legislation and regulations related to investment in Saudi Arabia

\begin{tabular}{|l|c|c|c|c|c|}
\hline Source & SS & DF & MS & $\begin{array}{c}\text { F- } \\
\text { value }\end{array}$ & Seg \\
\hline $\begin{array}{l}\text { Between } \\
\text { groups }\end{array}$ & 0.507 & 2 & 0.254 & 1.254 & 0.287 \\
\hline $\begin{array}{l}\text { Inside } \\
\text { groups }\end{array}$ & 40.228 & 199 & 0.202 & & \\
\hline Overall & 40.735 & 201 & & & \\
\hline
\end{tabular}

It shows from table (15) non-existence of statistically significant differences at level $(\alpha \leq 0.05)$, due to the investment period and this attributed to the fact that investment through E-Commerce in Saudi Arabia is a new and emerging sector.

- What is the impact of the investment field variable on the qualified manpower in Saudi Arabia?

Table 16: One-Way ANOVA for the impact of the investment field on the qualified manpower in Saudi Arabia

\begin{tabular}{|l|c|c|c|c|c|}
\hline Source & SS & DF & MS & $\begin{array}{c}\text { F- } \\
\text { value }\end{array}$ & Seg \\
\hline $\begin{array}{l}\text { Between } \\
\text { groups }\end{array}$ & 1.123 & 6 & 0.187 & 1.201 & 0.308 \\
\hline $\begin{array}{l}\text { Inside } \\
\text { groups }\end{array}$ & 30.408 & 195 & 0.156 & & \\
\hline Overall & 31.531 & 201 & & & \\
\hline
\end{tabular}

It shows from table (16) non-existence of statistically significant differences at level $(\alpha \leq 0.05)$, due to the investment field and this attributed to the fact that E-Commerce fields are open and diverse, and aren't restricted to a particular area. This was confirmed by the study of Ministry of Trade and Investment in the Kingdom for $2017 \& 2018$ respectively since the majority of electronic stores aren't restricted to a particular commodity but instead seek to provide customer demands from the different goods that are displayed on the local and international networks.

\subsection{Discussion of the Study's Hypotheses and Results}

First Hypothesis: there is a statistically significant relationship at the level $(\alpha \leq 0.05)$ of E-Commerce on investment at the Kingdom of Saudi Arabia that attributed to the independent variables (infrastructure, regulations and legislations, manpower).

The results indicate a statistically significant impact of ECommerce on motivating investment, where the correlation coefficient amounted to $(\mathrm{R}=0.736)$, which indicate a statistically significant correlation between the independent variables (infrastructure, regulations and legislations, manpower); as a 
whole on motivating the investment. The results also showed that $(\mathrm{R} 2=0.542)$, which indicates that E-Commerce explains $54.2 \%$ of the variation that occurs in investment motivation while the rest is due to other variables that didn't take part of the model. In addition, the value of $(\mathrm{F}=77.996)$ at a confidence level of ( $\mathrm{sig}=0.000)$ which confirms the significance of regression at the level of $(\alpha \leq 0.05)$.

It shows from the Coefficient tables that (B) values at the infrastructure dimension amounted to (0.098) and that $\mathrm{t}$-value is (2.025) at a statistically significant of (0.044), which indicate that the impact of this dimension is significant, and means that an increase in the independent by one unit will lead to an increase in investment motivation by (0.098).

It shows from the Coefficient tables that (B) values at the regulations and legislations dimension amounted to (0.147) and that t-value is (2.716) at a statistically significant of (0.007), which indicate that the impact of this dimension is significant, and means that an increase in the independent by one unit will lead to an increase in investment motivation by $(0.147)$.

It shows from the Coefficient tables that (B) values at the Manpower dimension amounted to $(0.480)$ and that $\mathrm{t}$-value is (8.835) at a statistically significant of (0.000), which indicate that the impact of this dimension is significant, and means that an increase in the independent by one unit will lead to an increase in investment motivation by $(0.480)$.

See table (6) that shows the results of the Multiple Linear Regression Test related to the impact of E-Commerce (Regulations and Legislations, Infrastructure, Manpower) on motivating the investment in Saudi Arabia. The above results prove the validity of the first hypothesis.

\subsection{Hypothesis}

there is no statistically significant relationship at the level $(\alpha \leq 0.05)$ of E-Commerce on investment in Saudi Arabia, due to the personal variables (age, gender, educational level):

Age: after conducting the dimensional comparisons of Scheffe Method for the impact of age on investment in Saudi Arabia, it shows from the table (12) the existence of statistically significant differences at $(\alpha=0.05)$ between (31-40) \& (41 and above), where the differences came in favour of (31-40).

Gender: by examining the results of table (11), such as arithmetic means, standard deviations, and T-test for the impact of gender on investment in Saudi Arabia, it shows non-existence of statistically significant differences at $(\alpha=0.05)$, due to the impact of gender.

Educational level: After conducting the One-Way ANOVA analysis for the impact of the educational level on investment in Saudi Arabia, it shows from table (13) non-existence of statistically significant differences at the level $(\alpha=0.05)$, due to the impact of educational level.

\section{Results and Recommendations \\ 12.1 Results}

This part aims to discuss the findings, and indicate the conclusions and recommendations of the study based on the results of statistical analysis, where the research has reached a set of conclusions and recommendations that can be presented as follows:

- The existence of a statistically significant impact of ECommerce on investment motivation with a Correlation Coefficient of $(\mathrm{R}=0.736)$, which indicate a statistically significant correlation between the independent variables (Regulations and Legislations, Infrastructure, Manpower) as a whole to motivate the investment.

- The results showed that an increase in regulations and legislations of E-Commerce by one unit would lead to an increase in investment motivation by $(0.147)$.

- The results showed that an increase in qualified Manpower of E-Commerce by one unit would result in an increase in investment motivation by $(0.480)$.

- The materiality of infrastructure items as a whole came high, where the total arithmetic mean amounted to (3.70) and the standard deviation (.522), which reflect the investors' interest in infrastructure to build and develop the E-Commerce, and this imposes on the state and private sector to spend and invest more in this field.

- The non-existence of statistically significant differences at the level $(\alpha=0.05)$ on the direction of sample members to invest in Saudi Arabia; due to the impact of gender.

- The existence of statistically significant differences at the level $(\alpha=0.05)$ among the investors in E-Commerce, according to the age groups, where the differences came in favour of the group (31-40).

- The non-existence of statistically significant differences at level $(\alpha=0.05)$ on the direction of sample members to invest in Saudi Arabia; due to the impact of educational level.

- The non-existence of statistically significant differences at level $(\alpha=0.05)$ on the direction of sample members to invest in Saudi Arabia; due to the impact of investment level.

- The non-existence of statistically significant differences at level $(\alpha=0.05)$ on the direction of sample members to invest in Saudi Arabia; due to the impact of the investment period.

- The non-existence of statistically significant differences at level $(\alpha=0.05)$ on the direction of sample members to invest in Saudi Arabia; due to the impact of investment field.

\subsection{Recommendations}

Depend on the findings of this study as well as the observations that were made by the study sample. The researchers made the following recommendations and suggestions: 
- Conduct the studies in the research topic and intensifying it by using different research methods, due to the shortage of studies that cover the topic, where there are studies related to E-Commerce and studies related to investment. Still, there is a scarcity of studies that link the E-Commerce with investment.

- E-Commerce in Saudi Arabia still needs more regulations and development to keep pace with the Kingdom Vision/ 2030 to convert $85 \%$ of the retail sector into the ECommerce, and this calls for practical scientific studies at the state level to establish a structured and progressive mechanism for the transformation.

- The study results showed a statistically significant difference for the age group (31-40) on the investment and this creates a motive to conduct additional studies on this group to make the most of it, since the majority of Saudi society included in this group.

- The kingdom's massive geographical area is a burden on the state to provide the full and appropriate infrastructure for the development of E-Commerce and to benefit from its gains, which form a field to search for the best possible ways to activate the private sector and civil society as a government partner in building the attractive investments.

\section{References}

- Al-Abeidi, Farahat (2012), "Investment Environment", Arab Society Library for Publishing and Distribution, Jordan

- Al-Hadi, Suleiman Omar (2015), "FDI and Environmental Rights", Academics for Publishing and Distribution, First Edition, p. (23.22), Jordan

- Al-Heiti, Salah Al-Dein (2004), "The Statistical Methods in Management Sciences", Dar Wael for Printing and Publishing, p. (223), Amman, Jordan

- Al-Jabbar \& Ahmed, Daoud (2018), "The History of Rational Thought for Investing in Human Capital", Journal of Economic and Administrative Sciences, Issue (103), Volume (24), Baghdad University

- Al-Jadran, Yahiya (2019), "The Saudi investment system under The Kingdom's Vision 2030 - the problematic conflict between FDI attraction and its discipline" - (a comparative critical analytical study with the World Bank rules), research published in Al-Jeal journal

- Al-Jazar, Sarah (2019), "Incentives and the qualified factors for the investment environment in the Arab world based on best practices", Union of Arab Chambers, Economic Department, Alexandria

- Al-Khattab, Mohammed Abdullah (2016), "Impact of Foreign Direct Investment on the Domestic Investment in Saudi Arabia", Baghdad College Journal for Economics, No. 49, Baghdad

- Allam, Rashid (2010), "Obstacles of E-Commerce Development in the Arab World, a Case study of Algeria", Master Thesis, Arab-British Academy for Higher Education, Algeria
- Al-Maghribi, Ibrahim Metwalli Hassan (2011), "The role of investment incentives in accelerating the economic growth; from the perspective of Islamic economics and the contemporary economic systems", University Thought House, Alexandria

- Al-Qahtani, Ali (2004), "Future of Investment in Saudi Arabia", Investment and Finance Conference, Sharm ElSheikh, Egypt

- Al-Taie, Hammad (2010), "E-Commerce as the Promising Future for Future Generations", Culture Publishing House, Jordan

- Al-Zain, M. (2012), "Investment Promotion and Its Impact on the Economic Development", Dar Al-Raya for Publishing \& Distribution, Amman

- Arafah, Mohammed (2009), "The effects of E-Commerce on the macroeconomics of the state", economic magazine, electronic version, (Aleqt.Com)

- Bassioni, Abdul Karim (2003), "E-Commerce", International Book House for Publishing, Cairo

- Fendi, Muhannad Ibrahim \& Turki, Bushra Khalid (2013), "Legal Organization for Foreign Real Estate Investment: A Comparative Study", Rafidain Law Journal, (M: 18), (P: 58), Iraq

- Ghoneim, Rafat (2002), "The Role of Arab League in Facilitating Trade", Working paper presented at the Arab League, Cairo

- Gujarati, D.N. (2004) Basic Econometrics. 4th Edition, McGraw-Hill Companies

- Hammad, Tarek Abd-AlAl (2003), "E-Commerce Concepts and Challenges", University House for Books, Cairo

- HE Yong, LI Jun-yang, WU Xue-pin, and JIANG Jiao-Jiao، Impact of E-Commerce on International Trade - Based on an Iceberg Cost Model

- https://jilrc.com/\%D9\%86\%D8\%B8\%D8\%A7\%D9\%85

- https://unctad.org/searchcenter/Pages/Results.aspx?r=uncta dlanguage

- https://www.misa.gov.sa/ar/

- International Journal of Trade, Economics and Finance, Vol. 2, No. 3, June 2011.

- Ismail, Shaker Turki (2010), "E-Marketing and competitive advantage at Jordanian banks, a field study on the Jordanian banks", Journal of humanities, 7(45), 1-27

- Jibreal, Saeed Saleh (2012), "The Reality of E-Commerce in Palestine and Future Challenges", Master's Thesis, Al-Azhar University, Faculty of Economics and Management Sciences, Gaza

- Nour Al-Dein, Bou Anan (2007), “Quality of services and their impact on customer satisfaction, a field study at Skikda Institutions", Master Thesis, Mohamed Boudiaf University, Al-Maseilah, Algeria

- Qandeelji, Amer (2015), "E-Commerce and its Applications", Dar Al-Maseirah for Publishing, Distribution, and Printing, V1, Amman 
- Rafat, Radwan (1999), "The world of E-Commerce", Arab Organization for Administrative Development, Egypt, Cairo, p. 94

- Report of the United Nations Conference for Trade and Development (2017),

- Saudi Investment Promotion System Project, Article 1, (2019)

- Sekaran, U. \& Bougie, R. (2010), "Research methods for business: A skill-building approach", (5th Ed.), Haddington, John Wiley \& Sons

- Serrah, Kriemah (2014), "The reality and prospects of ECommerce in Algeria", unpublished study for a master's degree in commerce, Wahran

- The collaboration between Ministry of Commerce and Investment, and the General Authority for Small and Medium Enterprises on digital researches (2017), "The study of E-Commerce in Saudi Arabia for micro and small entities" 